\title{
THE SAFETY AND SECURITY OF THE TOURISM ENTREPRENEURSHIP POTENTIAL REALIZATION IN MODERN CONDITIONS
}

\author{
Iryna Mazur', Ramil Aliyev², Yuliia Zhelizko³
}

\begin{abstract}
The purpose of the paper is to determine the relationship between different types of tourism safety and security, and components of the tourism entrepreneurship potential, to conduct a quantitative analysis of these indicators in the regions of Ukraine and to identify areas for ensuring the safety and security of the tourism entrepreneurship potential realization. Methodology. Analysis of tourism safety and security in Ukraine is based on the assessment of security potential indicator and the security threats indicator for 25 regions. These indicators take into account the following types of safety and security: security of tourist services, safety of tourist facilities and equipment, social security, political security, financial security, medical safety, information security, and ecological security. The impact of tourism safety and security on the tourism entrepreneurship potential realization is determined on the basis of correlation and regression analysis, where the indicator of the tourism entrepreneurship potential realization is the volume of domestic and inbound tourist flows in the region. The empirical basis of the study is the data of the State Statistics Service of Ukraine for 2019. The reliability of the regression model was tested on the basis of the approximation coefficient and Fisher's F-test. Results of the correlation analysis indicate a significant relationship between ensuring the safety and security of tourism in the region and the volume of domestic and inbound tourist flows. As a result of regression analysis, a model of a high level of reliability was obtained, which indicates how the volume of domestic and inbound tourist flows to the region increases with increasing the level of tourist safety and security by unit. Practical implications. Since the process of safety and security ensuring for the tourism entrepreneurship potential realization cannot be implemented exclusively at the regional level, it is justified the feasibility of a targeted public policy in eight areas. Value/originality. The identified relationship between the types of safety and security of tourism and components of the tourism entrepreneurship potential, as well as establishing the level of impact of safety and security of tourism on the tourism entrepreneurship potential realization in the region provide for a better understanding of ways for efficient governance in this area.
\end{abstract}

Key words: entrepreneurship potential, guarantee of tourism security, realization of potential, safety and security of tourism, types of safety and security.

JEL Classification: D24, L83, R11, Z30

\section{Introduction}

In recent decades, economic systems at various levels have been characterized by instability thresholds. Global economic crises, military-political conflicts, the growth of terrorist threats and other destructive factors determine the state of uncertainty about the prospects for human development in the $21^{\text {st }}$ century.
In view of this, the problems of security are becoming increasingly important, which is interpreted not only as a state of protection from threats, but also as an opportunity for development and even a condition for the survival of entire states and regions.

Threats and challenges of modern social development have not escaped tourism, which,

\footnotetext{
Corresponding author:

${ }^{1}$ Taras Shevchenko National University of Kyiv, Ukraine.

E-mail: iimazur@ukr.net

ORCID: https://orcid.org/0000-0002-2441-8001

ResearcherID: https://publons.com/researcher/1932003/iryna-i-mazur/

${ }^{2}$ Taras Shevchenko National University of Kyiv, Ukraine.

E-mail: aspirants7782@gmail.com

ORCID: https://orcid.org/0000-0002-6122-9234

${ }^{3}$ Taras Shevchenko National University of Kyiv, Ukraine.

E-mail: bodikova03061@ukr.net

ORCID: https://orcid.org/0000-0003-1205-1166
} 
on the one hand, is one of the most promising and profitable economic activities, and on the other hand, is extremely susceptible to destructive factors of various origins.

The spread of international terrorism, illegal migration, the growing incidence of socially dangerous diseases, the general deterioration of the environmental situation, along with the intensification of tourist flows, lead to a significant increase in the scale of the negative consequences of regional tourism problems.

Crisis and risk situations are an obstacle to realization of the tourism entrepreneurship potential at the global, national and regional levels. Particularly acute is the issue of ensuring the security of the potential of tourism business in the current crisis environment, which has been formed because of the spread of coronavirus Covid-19.

\section{The tourism entrepreneurship potential and its components}

The modern complex concept of studying the "entrepreneurship potential" has a number of advantages over resource, production and strategic approaches, because it allows to cover those aspects of business that can ensure the growth of future incomes. For example, Horyn $\mathrm{H}$. adheres to a comprehensive approach to the interpretation of this concept, defining that the "tourism entrepreneurship potential" is a holistic set of available resources and opportunities in the region that can be used in order to ensure the activities of tourism enterprises and achieve sustainable development of the region (Horyn, 2014).

The carriers of entrepreneurial potential can belong to any hierarchical level of the economy - mega-level, macro-level, meso-level, and micro-level (Kvasnytska, 2017). Therefore, it is advisable to determine the level of the economy within which the structure of entrepreneurial potential is most fully reflected. The answer to this question depends on the specifics of an industry.

Features of business in the tourism industry are follows:

a) The number of target consumers of the tourist product may significantly exceed the available supply of the enterprise and the region;

b) The demand for tourist services is formed at the expense of geographically remote consumers;

c) In the process of a tourism product selling, services are not delivered to the consumer, but on the contrary, i.e. the consumer (tourist) is sent to the place where the relevant tourist services are provided. In this case, the tourism product can be purchased both at the place of residence of the consumer and at the place of production;

d) Lack of possibility of accumulation and return of a tourism product; e) The greater the value of tourism services for the consumer, the more complex they are.

Thus, the potential of entrepreneurship cannot be considered within a single company, because its services are only one part of a range of tourism services provided to consumers, in addition, no company in this area operates completely autonomously, and therefore is under the direct and indirect influence of external environment. Macro-level and mega-level determine the general trends in the formation of entrepreneurship potential, but should be considered in terms of territorially separated units. Based on the above, the entrepreneurship potential should be explored at the meso-level, because a complex tourism product depends on the supply chain operating within regional boundaries.

An important aspect in the process of defining the essence of the "entrepreneurship potential" is the justification of its constituent elements. This point is especially relevant in matters relating to such a comprehensive concept as "potential".

The theoretical approaches of modern scientists in one way or another relate to the main factors of production, because they contain the potential for development:

1. Capital relates to the following concepts: production and financial capabilities, inventories and funds, financial and economic potential, investment potential, production potential, technical potential, potential of fixed assets, potential of fixed and working capital, financial and investment potential, tax potential, material financial potential, property potential. It is not advisable to combine all these concepts into one component of the entrepreneurship potential, because they relate to various aspects of business. We offer to pay attention to the investment, production and tax components.

Yepifanova I. and Bardadyn O. give an accurate definition of "investment potential": organized set of available economic resources and opportunities for enterprise development, which is achieved through the implementation of opportunities to mobilize internal and external investment to achieve strategic and tactical goals of the enterprise through the investment mechanism (Yepifanova, 2017). This interpretation indicates all possible sources of financing for business activities.

Romanchyk T. and Pavlenko Ye. under the production potential understand mean "the set of cost and physical characteristics of the production base, which is expressed in the potential to create products of a certain composition, technical level and in the required amount" (Romanchyk, 2017).

Brezhnieva-Yermolenko O. and Misiuchenko A. note that the tax potential is the basis for the formation of the tax revenue part of the budget, i.e. covers the part of the financial resources of the region that fill the local budget (Brezhnieva-Yermolenko, 2016). 
2. Land as a factor of production covers the following concepts: natural conditions and resources, environmental conditions, availability of natural resources, natural resource potential. Among the proposed concepts, the most holistic is the natural resource potential, as one that covers both natural resources and environmental opportunities. Zhulavskyi A. and Hordiienko V. propose the following definition of the natural resource potential of the region - "a set of natural resources and natural conditions that in the complex can provide the maximum possible production of consumer values at this stage of development of productive forces and production relations, while maintaining the ability to sustainable reproduction" (Zhulavskyi, 2013).

3. The labor concerns the following concepts: intellectual opportunities, work opportunities, human resources, creative potential, motivational potential, labor potential, social potential. Special attention should be paid to social potential, as one that reflects the effectiveness of public administration to meet the interests of the population, which is the main resource of the productive sphere (Valenkov, 2017).

4. The information factor is outlined in the following concepts: information potential, innovation potential, technological potential, scientific and technical potential, technical and technological potential. These concepts should be combined in the information and innovation component, because it is responsible for ensuring the competitiveness and economic growth of the region (Kyrychenko, 2017).

Based on a comprehensive approach to the interpretation of the essence of the potential of entrepreneurship, we propose to identify six of its components: production potential, social potential, investment potential, tax potential, information and innovation potential, and natural resource potential.

Thus, the tourism entrepreneurship potential is an opportunity to carry out economic activities in a particular region, which is due to production, social, investment, information and innovation, tax and natural resource components.

\section{Safety and security in the process of the tourism entrepreneurship potential realization}

There is no comprehensive definition of the term "tourism security" in the scientific literature. As noted by Niemisalo N. "safety and security is formulated bottom-up - from people and local community needs and the grass-roots level. Social groups, such as ethnic minorities, define their safety and security needs between the individual and state and across state borders. Similar to this broader thinking on safety and security, social security, health care systems and other well-being services and associations also represent safety and security policies” (Niemisalo, 2014). Kôvári I., and Zimányi Z. justify that "security and safety has become a complex multidimensional notion with a wide range of components belonging to it" (Kôvári, 2017). These interpretations of the concept suggest that the "safety and security of tourism" is revealed through the prism of its components.

According to Kôvári I., and Zimányi Z., tourism security consists of "political security, public safety, health and sanitation, personal data safety, legal protection of tourists, consumer protection, safety in communication, disaster protection, environmental security, getting authentic information, quality assurance of services" (Kôvári, 2017).

Cherednychenko $\mathrm{O}$. and Cherednychenko A. present a broader classification, namely: geopolitical, political and military-political security of tourism; political and legal security; religious, cultural; criminal, security in emergency situations (including terrorist attacks); life safety (medical, food safety, safety of accommodation services); financial (currency); ecological, recreational; traffic safety (transport); engineering, technological (safety of buildings and equipment); informational (Cherednychenko, 2016).

We consider Holod A. offers the most comprehensive grouping of the tourism safety and security types (Holod, 2016):

- Security of tourist services: food security, security of transport services, security of accommodation services, safety of recreational activities;

- Safety of tourist facilities and equipment: technological security, engineering safety;

- Social security: cultural security, demographic security, public security;

- Political security: geopolitical security, military and political security, political and legal security;

- Financial security: market security, currency security;

- Medical safety: health safety of tourists, safety of medical services;

- Information security: security of personal data, information environment security;

- Ecological security: safety of ecosystems in tourism, life safety in tourism, emergency safety.

Due to the fact the components of the tourism entrepreneurship potential correspond to certain types of the tourism security, they are in direct interdependence. Therefore, the formation of a certain level of the tourism entrepreneurship potential and the tourism safety and security determines the volume of tourist flows to the region (Figure 1).

It should be noted that medical security and political security are the types that affect the whole process of formation and realization the tourism entrepreneurship potential in the country. To determine the areas of ensuring tourism security, it is necessary to analyze the indicators of the tourism entrepreneurship potential 


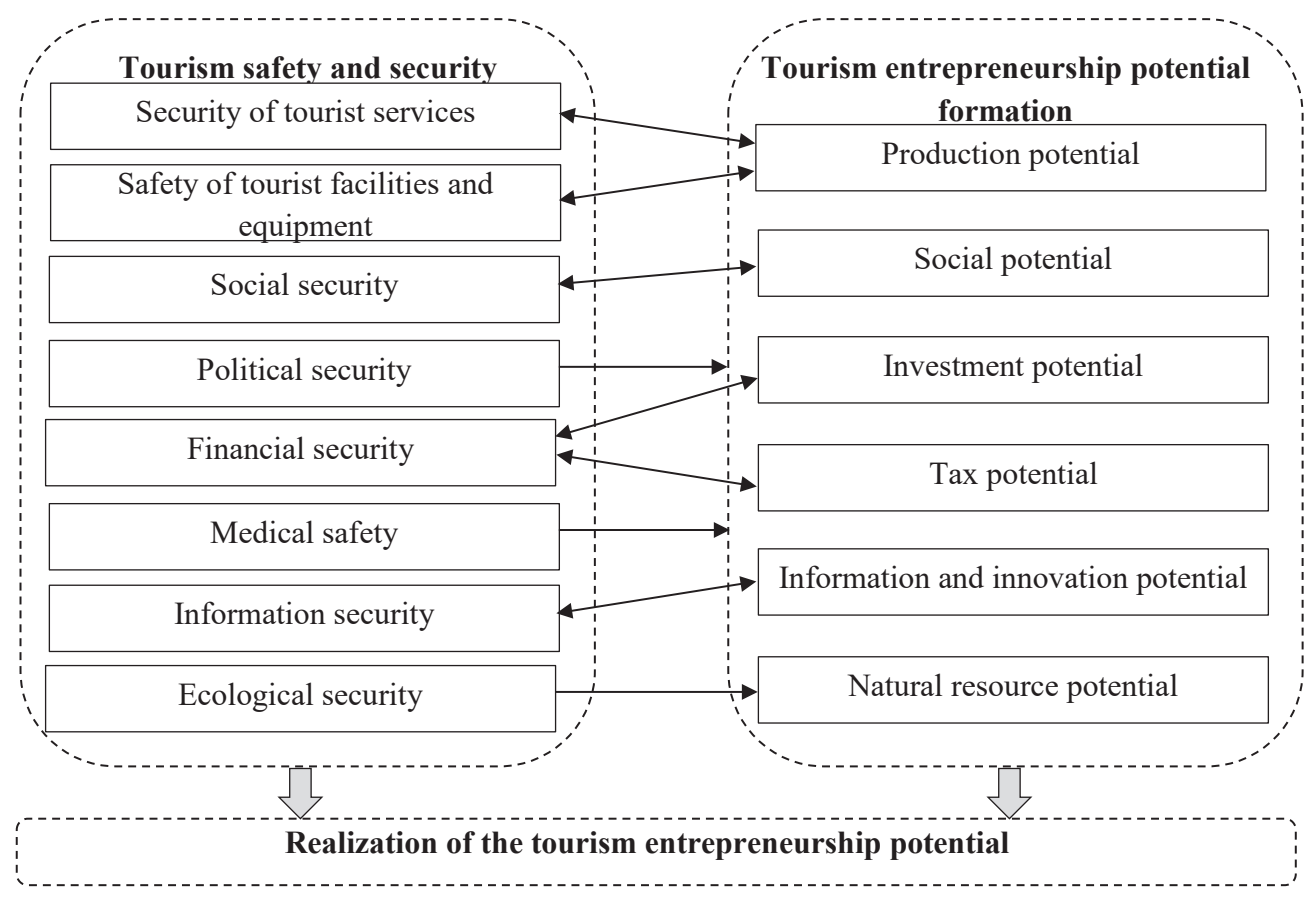

Figure 1. Safety and security in the process of formation and realization of the tourism entrepreneurship potential

realization and the level of security in the regional context.

4. Analysis of tourism safety and security in Ukraine and its impact on the tourism entrepreneurship potential realization

The domestic methodology for assessing the level of security of regional tourist systems (Holod, 2017) takes into account the above types of security. The level of tourism safety is interpreted as the difference between the integrated indicators of security potential and security threats $(1)$.

$$
S=\sum_{k=1}^{n} \frac{p_{n}-p_{\min }}{p_{\max }-p_{\min }}-\sum_{k=1}^{n} \frac{t_{n}-t_{\min }}{t_{\max }-t_{\min }} ;
$$

$\mathrm{p}$ is the numerical value of the security potential indicator of the regional tourist system; $t$ is the numerical value of the security threats indicator of the regional tourist system.

An indicator of the tourism entrepreneurship potential realization is the volume of inbound and domestic tourist flows of a region (Aliyev, 2020). It is not advisable to take into account outbound tourist flows because they indicate the effectiveness of the formation of the tourism entrepreneurship potential in other regions, and therefore lead to distortion of the results of the study.

Based on this methodology, a study of the level of indicators of 25 regions of Ukraine in 2019 was conducted. The evaluation results are shown in Figure 2.

The highest values of the tourism safety and security index are typical for the city of Kyiv and Lviv region.
The next group of regions in terms of tourism security is formed by Ivano-Frankivsk, Volyn, Odesa, Ternopil and Chernivtsi regions. The lowest indicators of the tourism safety and security index are observed in Dnipropetrovsk, Kharkiv, Donetsk and Luhansk regions. In the last two regions, in particular, the indicators reach the minimum (negative) values, which significantly differ from the average level for the state. It should be noted that the value of the tourism safety and security index for Kyiv also significantly exceeds the indicator of Lviv region, which is in the second ranking.

According to the correlation analysis, there is a high level of relationship between the level of tourism safety and security and the tourism entrepreneurship potential realization $(0,719)$. With this in mind, a one-factor regression model of the tourism entrepreneurship potential realization was constructed (2).

$$
R=12,9 \cdot S \text {; }
$$

$R$ is the tourism entrepreneurship potential realization of region; $\mathrm{S}$ is the level of tourism safety of region.

The regression model is highly reliable: $\mathrm{R}^{2}=0.728$, a $\mathrm{F}_{\text {stat }}>\mathrm{F}_{\mathrm{cr}}\left(\mathrm{F}_{\mathrm{stat}}=34, \mathrm{~F}_{\mathrm{cr}}=2.79\right)$.

According to results of the model, if the level of tourism safety \& security of region increases by unit, then the number of inbound and domestic tourist flows increases by 12.9 thousand people. Therefore, there is a necessity to identify main directions for ensuring the security of the tourism entrepreneurship potential realization in Ukraine. 


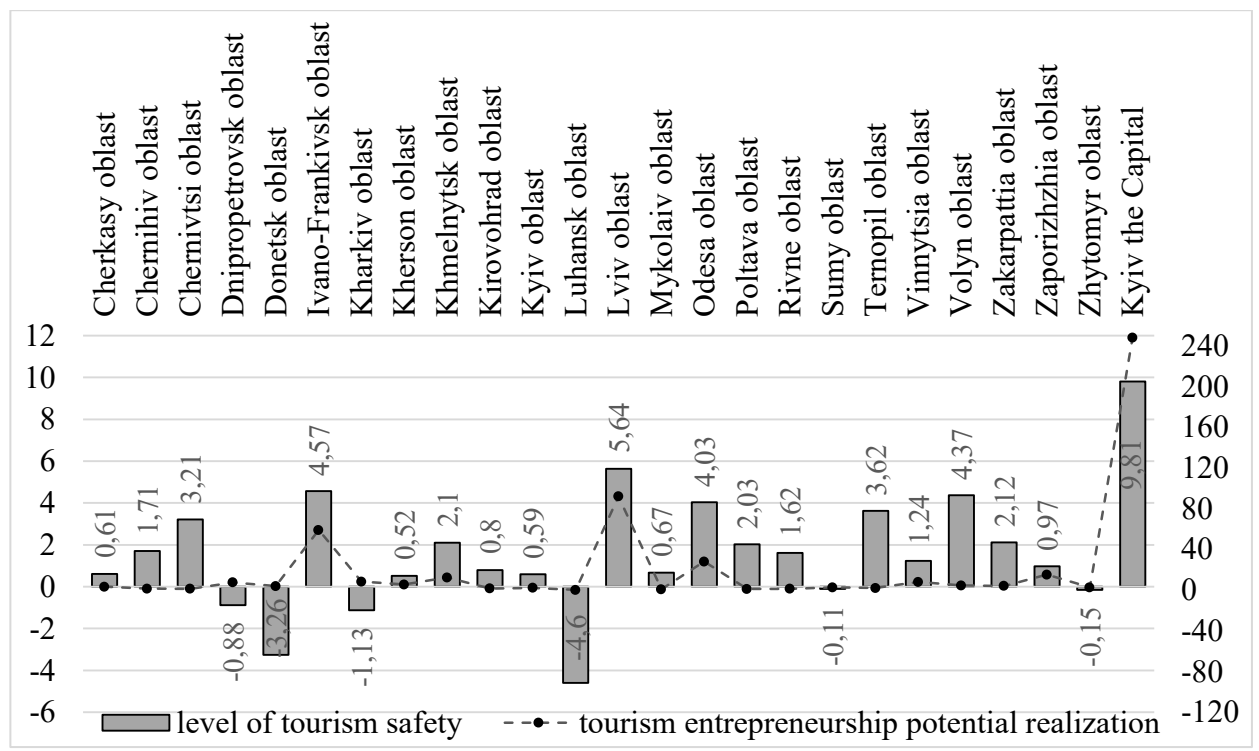

Figure 2. Results of assessment the level of tourism safety and security and the tourism entrepreneurship potential realization in Ukraine

\section{Directions for ensuring the safety and security of the tourism entrepreneurship potential realization in Ukraine}

Tourism in modern conditions is an extremely dynamic sector of the economy and an integral part of most regional social systems. At the same time, along with the intensive development and territorial expansion of tourism, the problems of tourism security (socio-economic, political and legal, environmental, socio-cultural, etc.) are becoming increasingly important. The contradictions of the development of modern tourism are especially clear at the regional level, especially in large tourism centers and border areas. It is becoming obvious that the intensive development of the tourism business, without taking into account the regional features of socio-economic development, can also cause destructive consequences for the economy and social sphere of the region.

An important issue is the relationship between different levels of security - regional, national, and global. Given the specifics of the safety \& security of tourism itself, there could be no clear hierarchy, because the regional tourism entrepreneurship potential is open enough to be influenced by global factors, regardless of the national environment. Thus, along with the decisive influence of the security of the tourist complex of the state, the security of the regional tourism entrepreneurship potential realization is also directly affected by factors related to the security of tourism at the global level.

Efficient safety \& security system in tourism has to provide increase of inbound and domestic tourist flows. Though, it is necessary to improve the effectiveness of strategic planning and management in the field of tourism in general, the quality of tourism services and the system of control of such quality (in particular by government agencies), transport, utilities and other infrastructure, and the system of medical services. In addition, there is a need to form positive image of the regions of the state as favorable for tourism development, and provide the system of information support for tourism development. The implementation of programs and measures to ensure the safety and security of tourism in the regions requires strong financial support as well as international cooperation in the field of tourism safety \& security.

In this context, it is advisable to implement a purposeful state policy in the field of tourism safety and security in the following areas:

1. Coordination of activities of state authorities, regional authorities, local governments, tourism enterprises and organizations, and local communities to ensure tourism safety and security.

2. Facilitating research on the analysis of methodological and practical problems of tourism safety and security at the regional level.

3. Improving the training system in accordance with the needs of the market in the field of tourism in order to widen a pool of professionals, which can create safe travel services.

4. Increasing and diversifying mechanism of public funding for the entrepreneurship potential formation and ensuring the tourism safety and security at the regional level.

5. Intensification of international cooperation of Ukraine with the EU countries in ensuring the tourism safety and security. 
6. Planning measures to eliminate the negative consequences of crises that threaten the safety and security of tourism.

7. Reforming the system of public management of tourism.

8. Regular monitoring of threats to tourism security and assessment of its current state at the regional level.

\section{Conclusions}

The study shows that tourism safety and security issues, particularly at the regional level, should be the subject of economic research. This is due to the close connection between certain types of security and components of the tourism entrepreneurship potential. The economic essence of tourism safety and security allows us to interpret it as the main prerequisite for sustainable development of tourism within destinations and regions, which is manifested in ensuring the realization of the tourism entrepreneurship potential. To this end, however, it is necessary to change the paradigm of tourism development at the regional level from object to subject. To fully guarantee the safety and security of tourism, the region must become the subject of this process, and not just the object of regional policy.

At the same time, with the implementation of effective state policy measures in the field of tourism security, in particular by implementing a purposeful state policy in the field of tourism safety and security, even in crisis conditions it is possible to obtain positive dynamics of regional tourist flows.

\section{References:}

Aliyev, R. (2020). Analysis of the tourism entrepreneurship potential realization in case of Ukraine. Modern Science, vol. 5, pp. 14-22.

Brezhnieva-Yermolenko, O. V., \& Misiuchenko, A. E. (2016). Rol podatkovoho potentsialu v zabezpechenni rozvytku rehionu [The role of tax potential in ensuring the development of the region]. Molodyi vchenyi, vol. 1, pp. 651-654.

Cherednychenko, O. Yu., \& Cherednychenko, A. O. (2016). Creation of the efficient system of tourism security as one of the main conditions for improvement of the competitiveness of the toruism industry of Ukraine. Visnyk ekonomiky transportu i promyslovosti, vol. 55, pp. 144-150.

Derzhavna sluzhba statystyky Ukrainy [State Statistics Service of Ukraine]. Retrieved December 4, 2020, from: http://www.ukrstat.gov.ua

Holod, A. (2016). Safety and security of tourism as an object of modern economic research. European Cooperation, vol. 3.10, pp. 72-80.

Holod, A. (2017). Bezpeka rehionalnykh turystychnykh system: teoriia, metodolohiia ta problemy harantuvannia [Security of regional tourist systems: theory, methodology and problems of guarantee]. Lviv: LDUFK. (in Ukrainian) Horyn, H. V. (2014). Systematyzatsiia metodolohichnykh pidkhodiv do vyznachennia sutnosti poniattia rekreatsiino-turystychnyi potentsial rehionu [Systematization of methodological approaches to defining the essence of the concept of recreational and tourist potential of the region]. Rehionalna ekonomika [Regional economy], vol. 2, pp. 187-199.

Kôvári, I., \& Zimányi, Z. (2017). Safety and security in the age of global tourism (The changing role and conception of Safety and Security in Tourism). Applied Studies in Agribusiness and Commerce. Budapest: Apstract Agroinform Publishing House, pp. 59-61.

Kvasnytska, R., \& Tarasiuk, M. (2017). Strukturyzatsiia potentsialu pidpryiemstva [Structuring the potential of the enterprise]. Visnyk Kyivskoho natsionalnoho torhovelno-ekonomichnoho universytetu [Bulletin of Kyiv National University of Trade and Economics], vol. 1, pp. 73-82.

Kyrychenko, M. O., \& Kyrychenko, N. A. (2017). Zarubizhnyi dosvid vysokorozvynenykh krain zi stalym rozvytkom informatsiino-innovatsiinoho suspilstva $\mathrm{v}$ umovakh transformatsii suchasnoi tsyvilizatsii [Foreign experience of highly developed countries with sustainable development of information and innovation society in the transformation of modern civilization]. Aktualni problemy filosofii ta sotsiolohii [Current issues of philosophy and sociology], vol. 17, pp. 51-54.

Niemisalo, N. (2014). Tourism Safety and Security: Findings from Tourism Intensive Finnish Lapland. Arctic Yearbook. Retrieved December 4, 2020, from: https:9/arcticyearbook.com/images/yearbook/2014/ Briefing Notes/3.Niemisalo.pdf

Romanchyk, T. V., \& Pavlenko, Ye. V. (2017). Konkurentnyi potentsial pidpryiemstva: sutnist poniattia [Competitive potential of the enterprise: the essence of the concept]. E-CONOMICS, vol. 1, pp. 136-140.

Valenkov, V. Ye. (2017). Rehionalni aspekty formuvannia ta otsiniuvannia sotsialnoho potentsialu derzhavy [Regional aspects of formation and assessment of the social potential of the state]. Investytsii: praktyka ta dosvid [Investments: practice and experience], vol. 21, pp. 123-126.

Yepifanova, I. Yu., \& Bardadyn, O. A. (2017). Sutnist investytsiinoho potentsialu pidpryiemstva [The essence of the investment potential of the enterprise]. Investytsii: praktyka ta dosvid [Investments: practice and experience], vol. 14, pp. 39-42.

Zhulavskyi, A. Yu., \& Hordiienko, V. P. (2013). Pryrodno-resursnyi potentsial rehionu v systemi ekonomichnykh vidnosyn [Natural resource potential of the region in the system of economic relations]. Efektyvna ekonomika [Efficient economy], vol. 8. Available at: http://nbuv.gov.ua/UJRN/efek_2013_8_22 